\title{
VEGETATIVE GROWTH AND YIELD OF STRAWBERRY UNDER IRRIGATION AND SOIL MULCHES FOR DIFFERENT CULTIVATION ENVIRONMENTS
}

\author{
Regina Célia de Matos Pires ${ }^{1 *}$; Marcos Vinícius Folegatti²; Francisco Antonio Passos ${ }^{3}$; Flávio \\ Bussmeyer Arruda ${ }^{1}$; Emílio Sakai ${ }^{1}$ \\ ${ }^{1}$ APTA/IAC - Centro de Pesquisa e Desenvolvimento de Ecofisiologia e Biofísica, C.P. 28 - 13001-970 - Campinas, \\ $S P$ - Brasil. \\ ${ }_{3}^{2}$ USP/ESALQ - Depto. de Engenharia Rural, C.P. 09 - 13418-900 - Piracicaba, SP - Brasil. \\ ${ }^{3}$ APTA/IAC - Centro de Horticultura. \\ *Corresponding author <rcmpires@iac.sp.gov.br>
}

\begin{abstract}
The vegetative growth and yield of strawberry in relation to irrigation levels and soil mulches are still not well known, mainly for different environmental conditions. Two experiments were carried out in Atibaia, SP, Brazil, during 1995, one in a protected environment and the other in an open field, to evaluate the cultivar Campinas IAC-2712, under different irrigation levels and soil mulches (black and clear polyethylene). Three water potential levels in the soil were used in order to define irrigation time, corresponding to $-0.010\left(\mathrm{~N}_{1}\right)$, $-0.035\left(\mathrm{~N}_{2}\right)$, and $-0.070\left(\mathrm{~N}_{3}\right) \mathrm{MPa}$, measured through tensiometers installed at the $10 \mathrm{~cm}$ depth. A $2 \times 3$ factorial arrangement was adopted, as randomized complete block, with 5 replicates. In the protected cultivation, the irrigation levels of -0.010 and -0.035 $\mathrm{MPa}$ and the clear plastic mulch favored the vegetative growth, evaluated through plant height, maximum horizontal dimension of the plant, leaf area index, as well as by total marketable fruit yield and its components (mean number and weight of fruits per plant). In the open field cultivation, no effect of treatments due to rainfall were observed.

Key words: Fragaria $\times$ ananassa Duch., trickle irrigation, water management, greenhouse

\section{DESENVOLVIMENTO VEGETATIVO E PRODUTIVIDADE DO MORANGUEIRO IRRIGADO, COM COBERTURAS DE SOLO EM DIFERENTES AMBIENTES DE CULTIVO}

\begin{abstract}
RESUMO: O desenvolvimento vegetativo e a produção do morangueiro submetido a diferentes níveis de irrigação e coberturas do solo ainda não é bem conhecido, principalmente para diferentes ambientes de cultivo. Foram instalados dois experimentos em Atibaia, SP, Brasil, em 1995, um em ambiente protegido e o outro em campo aberto, para avaliar o crescimento vegetativo e a produção da cultivar Campinas IAC-2712, sob diferentes níveis de irrigação e coberturas do solo (polietileno preto e transparente). Três níveis de potencial de água no solo foram utilizados a fim de determinar o momento de irrigação, correspondendo a -0,010 (N1), -0,035 (N2) e -0,070 (N3) MPa, medidos por tensiômetros instalados a $10 \mathrm{~cm}$ de profundidade. Os experimentos foram instalados em esquema fatorial $2 \times 3$, em blocos ao acaso com cinco repetições. No cultivo protegido, os níveis de irrigação de $-0,010$ e $-0,035$ $\mathrm{MPa}$ e a cobertura de solo com plástico transparente favoreceram o crescimento vegetativo, avaliado por meio da altura da planta, máxima dimensão horizontal da planta e índice de área foliar, além da produção total de frutos comerciáveis. No cultivo em campo aberto não houve efeito de tratamentos devido a ocorrência de chuvas durante o período experimental.

Palavras-chave: Fragaria $\times$ ananassa Duch., irrigação localizada, manejo da água, estufa
\end{abstract}

\section{INTRODUCTION}

Nowadays, strawberry production plays a significant role in the Brazilian agribusiness, the growing area being around 4,000 ha (Embrapa, 2006). The São Paulo State, second in importance, produced 22,412 t of strawberries on 645 ha in 2005 (IEA, 2006), the
Atibaia region having been the most important. The influence of the use of management techniques for the strawberry crop was intensively studied in different regions of the world, among these practices, soil mulching, irrigation, and protected cultivation are worth mentioning, because they significantly affect plant growth and yield. 
Protected cultivation has been used for strawberry cultivation in order to protect plants from harsh weather and for a better control of diseases (Passos, 1997; Goto \& Tivelli, 1998; Andriolo et al., 2002; Fernandes-Jr. et al., 2002). The adoption of protected systems for strawberry production in Brazil must be carefully evaluated and implemented, since a number of reports mention the occurrence of higher temperatures under protected environments in relation to field conditions, specially with regard to maximum temperatures (Montero et al., 1985; Farias et al., 1993; Pezzopane et al., 1995 and Alves \& Klar, 1996); this condition could be adverse for strawberry production (Iuchi, 1993), requiring an adaptation of cultural practices.

Conversely, irrigation is an essential technique for strawberry cultivation in Brazil due to crop sensitivity to water deficits (Voth, 1967; Hanson \& Bendixen, 2004). Crop sensitivity to water stress at different stages of development has strong interference on plant growth and yield (Krüger et al., 1999). The plant water status influences photosynthesis and consequently growth, since the occurrence of water deficit has direct action on metabolic and physiological processes, resulting in increased stomatal resistance (Iuchi, 1993). Stomatal opening is one of the main physiological processes affected under water stress conditions (Hsiao \& Acevedo, 1974), and is highly important because it is the main water passway controlled by the plant during gaseous exchanges. On the other hand, water excess conditions are also detrimental to strawberry growth, health, and yield (Voth, 1967). Within this context, studies that provide support to the rational use of water under different environmental conditions assume great importance (Hanson \& Bendixen, 2004).

The use of different soil mulches for strawberry cultivation has been extensively investigated. However, conflicting results have been observed with regard to their performance. This fact has been associated with edaphoclimatic factors, cultivation conditions, and cultivar (Passos, 1997).

The objective of the present study was to evaluate the vegetative development of the above-ground part and yield of strawberry submitted to different irrigation levels and soil mulches under protected cultivation and open field conditions.

\section{MATERIAL AND METHODS}

Two strawberry experiments were carried out, one as a protected crop and the other in the open field, in Atibaia, São Paulo State, Brazil $\left(25^{\circ} 07^{\prime} \mathrm{S}\right.$ and $46^{\circ} 50^{\prime} \mathrm{W}, 744 \mathrm{~m}$ above sea level). The climate is Cfa, according to Köppen's classification, defined as subtropical (upland), with a hot summer without a pronounced dry season.

In order to monitor environmental conditions, thermo-hygrographs were installed $(1.5 \mathrm{~m}$ above soil surface) in shelters located approximately $15 \mathrm{~m}$ away from the experiment in the open field, and in the center of the greenhouse. A pluviometer was also installed in the open field. Maximum, minimum, and mean temperature averages for both experiments, and precipitation totals were grouped in periods of 10 to 11 days, and are presented in Table 1.

The soil is a clayey-textured Typic Eutrudox, that was fumigated with Bromex ( $98 \%$ methyl bromide and $2 \%$ chloropicrin). Soil parameter corrections and pre-planting fertilization followed the recommendations of Raij et al. (1996). Post-planting fertilizations were performed based on leaf analysis, following Ulrich et al. (1980) interpretations and recommendations of Raij et al. (1996).

The protected cultivation was carried out in an even-span greenhouse, $7 \mathrm{~m}$ wide and $50 \mathrm{~m}$ long, covered with clear polyethylene, installed prior to planting. The largest side of the greenhouse was oriented in the northwest-southeast direction. The greenhouse height at the center was $3.0 \mathrm{~m}$, and $2.15 \mathrm{~m}$ at the sides. The greenhouse sides were protected up to a $0.75 \mathrm{~m}$ from the ground, and the remainder was maintained completely open during rainless days. The plots were installed in a parallel fashion in relation to the largest side of the greenhouse. A polyethylene film was introduced to a $70 \mathrm{~cm}$ depth around the greenhouse, in order to prevent rain water entrance.

Cultivar Campinas IAC-2712 runner plants were transplanted on April $20^{\text {th }}$ and $21^{\text {st }}, 1995$, according to the strawberry recommendation for the State of São Paulo (Passos et al., 1998). Planting was made in beds $0.30 \mathrm{~m}$ high and $1.20 \mathrm{~m}$ wide, spaced $0.50 \mathrm{~m}$ from each other, using a $0.30 \times 0.30 \mathrm{~m}$ spacing between plants. Fruits were harvested from June through December, whenever $75 \%$ of their surface was reddish.

Both experiments were implemented as a $2 \times$ 3 factorial scheme (soil mulches and irrigation levels), in randomized complete block design with 5 replicates, totaling 30 plots. In the open field, the plots consisted of beds $18 \mathrm{~m}$ long and $1.2 \mathrm{~m}$ wide; in the protected cultivation, each plot was $5.1 \mathrm{~m}$ long. There were 240 plants per plot in the open field, and 68 plants per plot in the protected cultivation. These plot size differences were adopted because in the open field beds included four sub-plots from which plants were sampled to evaluate dry matter along the crop cycle. The yield evaluation plots were identical in both experiments, 
Table 1 - Average maximum (max), minimum $(\min )$, and mean temperature $\left({ }^{\circ} \mathrm{C}\right)$ measured inside instrument shelters, under protected crop conditions and in the open field, and precipitation totals $(\mathrm{mm})$ observed in the period April $20^{\text {th }}$ to December $22^{\text {nd }}, 1995$, in Atibaia, Brazil.

\begin{tabular}{|c|c|c|c|c|c|c|c|}
\hline \multirow{3}{*}{ Period } & \multicolumn{3}{|c|}{ Protected crop } & \multicolumn{3}{|c|}{ Open field } & \multirow{3}{*}{ Precipitation } \\
\hline & \multirow[b]{2}{*}{$\operatorname{Max}$} & \multirow[b]{2}{*}{ Min } & \multirow[b]{2}{*}{ Mean a* } & \multicolumn{3}{|c|}{ Temperature } & \\
\hline & & & & $\operatorname{Max}$ & Min & Mean a* & \\
\hline & & & & $-\cdots$ & $-{ }^{\circ} \mathrm{C}$ & - & $\mathrm{mm}$ \\
\hline $04 / 20$ to $04 / 30$ & - & - & - & - & - & - & 6.2 \\
\hline $05 / 01$ to $05 / 10$ & - & - & - & - & - & - & 44.0 \\
\hline $05 / 11$ to $05 / 20$ & - & - & - & - & - & - & 0 \\
\hline $05 / 21$ to $05 / 31$ & 22.7 & 9.9 & 15.5 & 22.3 & 11.0 & 16.0 & 0 \\
\hline $06 / 01$ to $06 / 10$ & 24.8 & 7.3 & 14.4 & 24.6 & 9.2 & 16.1 & 0 \\
\hline $06 / 11$ to $06 / 20$ & 22.9 & 8.9 & 14.6 & 23.4 & 11.2 & 16.5 & 28.1 \\
\hline $06 / 21$ to $06 / 30$ & 23.6 & 11.4 & 16.3 & 22.0 & 11.6 & 15.9 & 20.4 \\
\hline $07 / 01$ to $07 / 10$ & 23.4 & 11.6 & 16.5 & 22.1 & 12.1 & 16.5 & 66.6 \\
\hline $07 / 11$ to $07 / 20$ & 26.7 & 11.4 & 17.5 & 24.6 & 11.6 & 16.9 & 0 \\
\hline $07 / 21$ to $07 / 31$ & 27.7 & 10.6 & 17.6 & 26.2 & 10.6 & 17.8 & 25.0 \\
\hline $08 / 01$ to $08 / 10$ & 26.5 & 11.8 & 17.5 & 25.3 & 11.6 & 17.8 & 7.6 \\
\hline $08 / 11$ to $08 / 20$ & 28.6 & 11.8 & 18.7 & 27.4 & 12.6 & 19.3 & 0 \\
\hline $08 / 21$ to $08 / 31$ & 30.8 & 10.5 & 19.5 & 29.5 & 10.7 & 19.6 & 0 \\
\hline $09 / 01$ to $09 / 10$ & 28.7 & 9.7 & 18.1 & 27.2 & 10.0 & 18.0 & 0 \\
\hline $09 / 11$ to $09 / 20$ & 26.3 & 13.1 & 18.4 & 25.6 & 13.6 & 18.8 & 10.4 \\
\hline $09 / 21$ to $09 / 30$ & 25.7 & 15.0 & 19.0 & 23.6 & 14.5 & 18.3 & 77.4 \\
\hline $10 / 01$ to $10 / 10$ & 28.9 & 14.6 & 20.3 & 28.5 & 15.8 & 20.8 & 8.0 \\
\hline $10 / 11$ to $10 / 20$ & 25.3 & 14.1 & 20.9 & 24.2 & 15.4 & 19.1 & 176.4 \\
\hline $10 / 21$ to $10 / 31$ & 27.9 & 11.8 & 19.8 & 27.0 & 13.3 & 21.7 & 81.4 \\
\hline $11 / 01$ to $11 / 10$ & 30.9 & 15.2 & 21.9 & 29.7 & 16.9 & 23.0 & 8.0 \\
\hline $11 / 11$ to $11 / 20$ & 26.7 & 14.9 & 20.1 & 26.0 & 16.3 & 20.3 & 24.6 \\
\hline $11 / 21$ to $11 / 30$ & 29.4 & 14.4 & 20.3 & 28.1 & 15.1 & 20.0 & 46.6 \\
\hline $12 / 01$ to $12 / 10$ & 29.8 & 15.2 & 21.3 & 28.8 & 16.2 & 21.6 & 21.8 \\
\hline $12 / 11$ to $12 / 22$ & 28.4 & 16.8 & 21.4 & 27.8 & 17.4 & 22.0 & 111.0 \\
\hline Total & & & & & & & 763.5 \\
\hline
\end{tabular}

$a^{*}$ Values estimated from the mean of two hour readings throughout the day. - Not measured values.

consisting of 40 plants $\left(3.6 \mathrm{~m}^{2}\right)$. The experimental areas were $943.5 \mathrm{~m}^{2}$ for the open field and $350 \mathrm{~m}^{2}$ for the protected cultivation.

Black $(30 \mu \mathrm{m}$ thick) or clear $(50 \mu \mathrm{m}$ in the greenhouse and $150 \mu \mathrm{m}$ in the open field) low-density polyethylene film (LDPF) was used as soil mulch. Black plastic is the more frequently used soil mulch in the State of São Paulo, and clear plastic has been successfully used for several cultivars and locations in the world (Voth \& Bringhurst, 1990). In the open field experiment, the soil mulches were installed on May $24^{\text {th }}$, and in the protected cultivation on June $1^{\text {st }}$.

During the runner plant establishment stage, irrigations were performed by sprinkling, divided into 2 to 6 times a day (until May $10^{\text {th }}$ ). The drip irrigation system was installed on May $10^{\text {th }}$, with drip emitters spaced at $0.3 \mathrm{~m}$ and with a flow rate of $1.74 \mathrm{~L} \mathrm{~h}^{-1}$. Two drip emitter tube lines were placed over each four plant-row bed, and each line was located between two rows of plants, except the central one. Until the beginning of the water level treatments, irrigations were performed whenever the water potential in the soil reached $-0.010 \mathrm{MPa}$, at a $10 \mathrm{~cm}$ depth. Starting on June $12^{\text {nd }}$ and $13^{\text {th }}$, water levels were differentiated. Three water potential levels in the soil were used in order to determine irrigation time, corresponding to $0.010\left(\mathrm{~N}_{1}\right),-0.035\left(\mathrm{~N}_{2}\right)$, and $-0.070\left(\mathrm{~N}_{3}\right)$ MPa measured by tensiometers installed at $10 \mathrm{~cm}$ depth. Three tensiometer stations were installed for each soil mulch and irrigation level combination; two of them with ten- 
siometers at depths of 10 and $20 \mathrm{~cm}$, and a third one with five tensiometers at depths of 10, 20, 30, 40, and $50 \mathrm{~cm}$. The irrigation depths were estimated from the soil water retention curve (Libardi, 2005). The tensiometers at depths of 20,30, 40 and $50 \mathrm{~cm}$ were used in order to monitor the soil moisture profile for adjustment, if necessary.

In order to evaluate the strawberry vegetative growth several samplings were taken from plants at blooming time and at the end of the cycle, after the last harvest, in both experiments. Evaluations of leaf area index, dry matter, plant height, and maximum horizontal dimension of plants were made to characterize the vegetative growth of strawberry, since they have also been adopted successfully by several authors (Lucchesi \& Minami, 1980; Olitta, 1980; Tessarioli Neto, 1993; Camargo et al., 1974; Iuchi, 1993; Passos, 1997).

In the open field experiment, four plant samplings were performed when more than $50 \%$ of the plants bore flowers in the plots, measuring the dry matter in the above-ground part (DMAGP), leaf area index (LAI), maximum horizontal dimension of the plant (HDP), and plant height (PH). Six plants were collected from the central rows in the sub-plots at each sampling time to determine DMAGP and LAI. Plants were cut at soil surface and in the laboratory they were washed and their leaflets separated from the petioles and fruits. The leaf area was scanned. Next, the leaflets, petioles, and fruits were dried in an oven at $70^{\circ} \mathrm{C}$ until constant weight. Finally, the samples were weighed, and DMAGP was obtained from the sum of dry matter from leaflets, petioles, and fruits. Three plants per plot were sampled at each bloom to evaluate $\mathrm{PH}$ and HDP.

Only tree blooms occurred in the protected cultivation, and the following parameters were evaluated for each of them: PH and HDP, number of leaves per plant, and leaflet width and length. The first bloom in the protected cultivation occurred before treatments were imposed; for this reason, during this bloom 25 plants were randomly sampled and the above-mentioned parameters were measured. In the second and third blooms, the same parameters were measured in three plants per plot. Leaf area was estimated according to Pires et al. (1999) using a leaf area measuring device (LICOR LI-3100); the total number of leaves per plant was tallied, and length and width were obtained for 15 leaflets, for three plants per plot.

On December $22^{\text {nd }}$, after the last harvest, three plants per plot were sampled to evaluate vegetative growth at the end of the cycle, in both experiments. The plants were removed with a shovel, to prevent damage to the root system. The excess soil attached to the roots was carefully removed. In the laboratory, the plants were washed, and the above-ground part was separated from the underground part at the plant root collar.

In the above-ground part of the plant, leaflets were separated from petioles and fruits. DMAGP was determined as previously described for the open field experiment. In order to determine dry matter in the underground part (DMUGP), the material was washed, dried in an oven at $70^{\circ} \mathrm{C}$ until constant weight, followed by final weighing.

After harvest, the fruits were classified as either marketable or unmarketable. Fruits with rots and imperfections were considered unmarketable. After classification, the fruits were counted and weighed.

The yield and vegetative growth results of each environment were submitted to analysis of variance and the F test. Means were compared by Tukey test, at $5 \%$. A split-plot design was used for the vegetative development analysis at various seasons during the cycle.

\section{RESULTS AND DISCUSSION}

For both environments total irrigation depths were similar when black and clear mulchings are compared at the same irrigation level. Therefore, the total water depths under protected cultivation were 580, 496 and $474 \mathrm{~mm}$, and in the open field 438, 380 and 336 $\mathrm{mm}$, at irrigation levels of $-0.010 \mathrm{MPa},-0.035 \mathrm{MPa}$ and $-0.070 \mathrm{MPa}$, respectively. In the open field rainfall was $764 \mathrm{~mm}$ in addition to irrigation during the cropping season.

The results obtained during the strawberry vegetative development cycle, at the four blooms in the open field and at the second and third blooms in the protected cultivation, can be found in Table 2. Because the plants in the protected environment reached the 1st sampling season (1st bloom) before the treatments could be differentiated (end of May), the vegetative development in this stage was characterized by measurements of PH, HDP, and LAI of 25 plants. The following means (and their corresponding standard deviations) were obtained: $\mathrm{PH} 10.4 \mathrm{~cm}(1.5 \mathrm{~cm})$; HDP $25.0 \mathrm{~cm}(3.1 \mathrm{~cm})$, and LAI $0.797(0.258)$.

The interactions between irrigation levels and soil mulches, irrigation levels and seasons (blooms), and soil mulches and seasons were not significant for all variables in the open field, and for HDP and LAI in the protected cultivation.

In the open field, there was no effect of soil mulches and irrigation levels on the analyzed variables (Table 2). The absence of irrigation level effect on plant development was probably associated with the 
Table 2 - Mean values of plant for height $(\mathrm{PH})(\mathrm{cm})$, maximum horizontal dimension of the plant $(\mathrm{HDP})(\mathrm{cm})$, dry matter in the above-ground part (DMAGP) (g), and leaf area index (LAI), obtained in 4 blooms of strawberry grown in the open field, and in the 2nd and 3rd blooms under protected cultivation, with different soil mulches and irrigation levels (MPa), in Atibaia, Brazil, 1995. a*

\begin{tabular}{|c|c|c|c|c|c|c|c|}
\hline & \multicolumn{4}{|c|}{ Open field cultivation } & \multicolumn{3}{|c|}{ Protected cultivation } \\
\hline & $\mathrm{PH}$ & HDP & DMAGP & LAI & $\mathrm{PH}$ & HDP & LAI \\
\hline \multicolumn{8}{|l|}{ Soil mulches } \\
\hline Clear plastic & $18.9 \mathrm{a}$ & $30.8 \mathrm{a}$ & $17.6 \mathrm{a}$ & $1.79 \mathrm{a}$ & $21.4 \mathrm{a}$ & $30.3 \mathrm{a}$ & $2.85 \mathrm{a}$ \\
\hline Black plastic & $18.3 \mathrm{a}$ & $31.2 \mathrm{a}$ & $17.0 \mathrm{a}$ & $1.75 \mathrm{a}$ & $18.9 \mathrm{~b}$ & $28.3 \mathrm{~b}$ & $2.24 \mathrm{~b}$ \\
\hline \multicolumn{8}{|c|}{ Irrigation levels (MPa) } \\
\hline-0.010 & $19.2 \mathrm{a}$ & $31.2 \mathrm{a}$ & $17.4 \mathrm{a}$ & $1.77 \mathrm{a}$ & $21.8 b^{*}$ & $31.0 \mathrm{a}$ & $2.89 \mathrm{a}$ \\
\hline-0.035 & $18.6 \mathrm{a}$ & $31.2 \mathrm{a}$ & $17.2 \mathrm{a}$ & $1.75 \mathrm{a}$ & $20.5 b^{*}$ & $29.5 \mathrm{ab}$ & $2.69 \mathrm{ab}$ \\
\hline-0.070 & $18.1 \mathrm{a}$ & $30.7 \mathrm{a}$ & $17.2 \mathrm{a}$ & $1.80 \mathrm{a}$ & $18.2 b^{*}$ & $27.5 \mathrm{~b}$ & $2.05 \mathrm{~b}$ \\
\hline \multicolumn{8}{|l|}{ Blooms } \\
\hline $1^{\text {st }}$ & $13.1 \mathrm{c}$ & $27.1 \mathrm{~b}$ & $9.7 \mathrm{c}$ & $1.13 \mathrm{c}$ & & & \\
\hline $2^{\text {nd }}$ & $18.1 \mathrm{~b}$ & $32.9 \mathrm{a}$ & $16.4 \mathrm{~b}$ & $1.58 \mathrm{~b}$ & $20.2 b^{*}$ & $29.6 \mathrm{a}$ & $2.60 \mathrm{a}$ \\
\hline $3^{\text {rd }}$ & 20.9 a & $32.8 \mathrm{a}$ & $25.4 \mathrm{a}$ & $2.23 \mathrm{a}$ & $20.1 \mathrm{~b}^{*}$ & $29.0 \mathrm{a}$ & $2.49 \mathrm{a}$ \\
\hline $4^{\text {th }}$ & $22.3 \mathrm{a}$ & $31.3 \mathrm{a}$ & $17.7 \mathrm{~b}$ & $2.15 \mathrm{a}$ & & & \\
\hline $\mathrm{CV}_{\text {plot }}(\%)$ & 7.7 & 4.9 & 12.4 & 11.9 & 12.3 & 7.9 & 29.2 \\
\hline $\mathrm{CV}_{\text {sub-plot }}(\%)$ & 13.0 & 8.8 & 14.8 & 15.1 & 16.2 & 14.1 & 29.9 \\
\hline
\end{tabular}

a*Means followed by the same letter are not different by Tukey test $(P<0.05)$. b*The interaction between water levels and sampling seasons was significant.

natural precipitations that occurred during the experimental period (Table 1). Significant differences in vegetative growth were observed with regard to sampling season (Table 2). The PH and LAI values were superior for the $3^{\text {rd }}$ and $4^{\text {th }}$ blooms, when compared to values obtained in the other blooms. For all variables, the smallest values were observed in the 1st bloom, and peak development was attained in the $3^{\text {rd }}$ bloom, except for PH and HDP. The occurrence of DMAGP and LAI peak values before the end of the cycle is similar to the obtained results by Lucchesi \& Minami (1980) and Olitta (1980), for the Piracicaba climatic conditions. However, they are different from those presented by Tessarioli Neto (1993), in Monte Alegre do Sul, SP, who observed that the values of these variables increased until the end of the crop cycle. HDP observed values were similar to those presented by Camargo et al. (1974), for the same cultivar in Jundiaí, SP, but were different in relation to $\mathrm{PH}$, being about $30 \%$ above the obtained values by these authors. With reference to DMAGP, the observed values in Table 2 are higher than those obtained by Lucchesi \& Minami (1980), specially in the initial blooms. They used the same cultivar (Campinas), however, these differences could be associated with the plant spacing $(35 \times 35 \mathrm{~cm})$ and soil mulch (wood shreds). At the beginning of October, DMAGP results (Table 2) were similar to those presented by Tessarioli Neto (1993), who also used the Campinas cultivar and black polyethylene as bed mulch. LAI values, presented in Table 2, were higher than those obtained by Tessarioli Neto (1993) and Lucchesi \& Minami (1980).

With regard to $\mathrm{PH}$ in the protected cultivation, only the interaction between water levels and sampling seasons was significant. In the $2^{\text {nd }}$ bloom, there was no effect of water levels on PH. However, in the $3^{\text {rd }}$ bloom, the measured $\mathrm{PH}$ values for soil water potentials of -0.010 and $-0.035 \mathrm{MPa}$ were significantly higher than those observed for the $-0.070 \mathrm{MPa}$ potential. In the $3^{\text {rd }}$ bloom, $\mathrm{PH}$ was significantly higher than that obtained in the $2^{\text {nd }}$ bloom, at the $-0.010 \mathrm{MPa}$ irrigation level., but at the $-0.070 \mathrm{MPa}$ water level the opposite occurred.

In the protected cultivation, according to results presented in Table 2, the clear polyethylene significantly favored plant growth (PH, HDP and LAI). In the protected cultivation, where precipitations did not occur, we were able to verify the effects of irrigation levels on the vegetative growth of strawberry (Table 2); a favorable significant difference was observed at the $-0.010 \mathrm{MPa}$ level when compared to the $-0.070 \mathrm{MPa}$ level. The $-0.035 \mathrm{MPa}$ level was not significantly different from the other. Possibly, the greater interval between irrigations that occurred in the driest treatment $(-0.070 \mathrm{MPa})$ affected plant development. The irrigation level effects on LAI, observed in Table 2, are similar to those presented by Serrano et al. (1992). With regard to soil mulch, it was verified that 
the obtained results in the protected cultivation and in the open field were different. These differences may be associated with differences in phytosanitary actions and environmental conditions to which the plants were submitted. The sampling season effect $\left(2^{\text {nd }}\right.$ and $3^{\text {rd }}$ blooms) on HDP and LAI values was not significant in the protected cultivation (Table 2). In spite of this, a tendency can be noticed that the vegetative development peaks occurred during the $2^{\text {nd }}$ bloom in the protected cultivation. In the open field cultivation, they predominantly occurred during the $3^{\text {rd }}$ bloom and a higher number of flowers was produced. This fact probably occurred due to higher maximum and amplitude temperatures in the greenhouse (Table 1) (Galletta \& Bringhurst, 1990). In the protected cultivation, the 1 st bloom was advanced by 15 days and a reduction in the number of blooms was observed. The $\mathrm{CV}$ values observed in Table 2 concerning the plots and sub-plots were smaller than $20 \%$, except for LAI. These values can be considered acceptable for field experimentation.

The results obtained for the final vegetative growth period of the plants at the end of both experiments (247 days after planting) are presented in Table 3 . The interaction between soil mulches and irrigation levels was not significant for all analyzed variables (DMAGP, DMUGP and LAI) in both cultivation environments.

No significant differences were observed in the protected cultivation for DMUGP, DMAGP, and LAI variables, in relation to soil mulches (Table 3). There was also no effect of irrigation levels on DMUGP. On the other hand, significant differences occurred for DMAGP and LAI variables with reference to irrigation levels. The DMAGP and LAI results were about $67 \%$ higher at the wettest irrigation level $(-0.010 \mathrm{MPa})$ when compared to those obtained at the driest level
$(-0.070 \mathrm{MPa})$. The obtained values at the intermediate water level did not differ significantly from the other.

The ranking of obtained results for LAI in the protected cultivation at the end of the experimentation (Table 3) was the same observed in Table 2 with regard to the effect of irrigation levels, and different with respect to the effect of soil mulches.

In the open field cultivation (Table 3), there was no effect of soil mulches or irrigation levels for all studied variables. The occurrence of diseases in a homogeneous manner in the plots, and of precipitations, possibly contributed to the fact that no significant differences were observed in the studied variables. The LAI values were similar in Table 2 and Table 3.

The DMUGP values were similar in both cultivation environments (Table 3), except for the -0.070 MPa water level, at which the value in the open field was $12.6 \%$ above that obtained in the protected cultivation.

In the last evaluation, the DMAGP values were higher for the open field cultivation, when compared to the protected cultivation, with increases of approximately 22 and $36 \%$, in relation to clear and black polyethylene soil mulches, respectively (Table 3 ). With regard to the $-0.010,-0.035$, and $-0.070 \mathrm{MPa}$ water levels, increases were of the order of 4, 26 and $70 \%$, respectively. Iuchi (1993) also observed smaller strawberry vegetative growth under protected cultivation, when compared to open field conditions. The CV values presented on Table 3 were larger than those presented on Table 2. This fact could be due to the weakening of the plants at the end of the harvest season leading to a greater variability.

Yield and its components were analyzed based on the total observed values during crop cycles. Unmarketable fruit yield was very low, less than $1 \%$, in

Table 3 - Mean values of dry matter in the underground part (DMUGP, in g), dry matter in the above-ground part (DMAGP, in $g$ per plant), and leaf area index (LAI) of strawberry in the open field and under protected cultivation, with different soil mulches and irrigation levels (MPa), on December $23^{\text {rd }} 1995$, in Atibaia, Brazil. a*

\begin{tabular}{|c|c|c|c|c|c|c|}
\hline & \multicolumn{3}{|c|}{ Open field cultivation } & \multicolumn{3}{|c|}{ Protected cultivation } \\
\hline & DMUGP & DMAGP & LAI & DMUGP & DMAGP & LAI \\
\hline \multicolumn{7}{|l|}{ Soil mulches } \\
\hline Clear plastic & $12.2 \mathrm{a}$ & $18.4 \mathrm{a}$ & $1.98 \mathrm{a}$ & $11.7 \mathrm{a}$ & $15.1 \mathrm{a}$ & $1.89 \mathrm{a}$ \\
\hline Black plastic & $12.2 \mathrm{a}$ & 15.9 a & $1.74 \mathrm{a}$ & $11.9 \mathrm{a}$ & $11.7 \mathrm{a}$ & $1.44 \mathrm{a}$ \\
\hline \multicolumn{7}{|c|}{ Irrigation levels $(\mathrm{MPa})$} \\
\hline-0.010 & $12.0 \mathrm{a}$ & $17.5 \mathrm{a}$ & $1.95 \mathrm{a}$ & $11.9 \mathrm{a}$ & 16.9 a & $2.15 \mathrm{a}$ \\
\hline-0.035 & $12.2 \mathrm{a}$ & $16.7 \mathrm{a}$ & $1.81 \mathrm{a}$ & $12.3 \mathrm{a}$ & $13.3 \mathrm{ab}$ & $1.55 \mathrm{ab}$ \\
\hline-0.070 & $12.5 \mathrm{a}$ & $17.2 \mathrm{a}$ & $1.81 \mathrm{a}$ & $11.1 \mathrm{a}$ & $10.1 \mathrm{~b}$ & $1.29 \mathrm{~b}$ \\
\hline $\mathrm{CV}(\%)$ & 20.1 & 27.8 & 28.8 & 22.1 & 35.6 & 38.1 \\
\hline
\end{tabular}

a*Means followed by the same letter are not different by Tukey test $(P<0.05)$. 
the open field cultivation, and was practically inexistent in the protected cultivation. The total yield, number of fruits per plant and mean weight of fruits verified in the protected cultivation and in the open field cultivation can be found in Table 4 .

In relation to total yield, number of fruits per plant and mean weight of fruits, the interaction between soil mulches and water levels was not significant in any of the environments.

For the protected cultivation an effect of soil mulching and irrigation levels was present on the analyzed variables (Table 4). The most favorable soil mulch was the clear polyethylene, for the 3 analyzed variables. Total yield and number of fruits were significantly higher at the water levels of -0.010 and $0.035 \mathrm{MPa}$, when compared to the obtained values at the $-0.070 \mathrm{MPa}$ level. With respect to mean weight of fruits, cultivation at the $-0.010 \mathrm{MPa}$ irrigation level resulted in a value higher than at the $-0.070 \mathrm{MPa}$ level. The $-0.035 \mathrm{MPa}$ irrigation level was not different from the other. It can be noted that yield and its components were favored in the treatments with greater vegetative growth (Tables 2 and 3) and the smaller intervals between imposed irrigation, similarly as observed by Passos (1997).

According to the presented results (Table 4), in the open field cultivation there was no effect of soil mulches and irrigation levels on variables total yield, number of fruits per plant and mean weight of fruits variables. The total yield achieved in both cultivation environments practically did not differ with the use of clear polyethylene (Table 4). On the other hand, total yield was $23 \%$ lower in the protected cultivation with black polyethylene, when compared to the obtained yield in the open field. The CV values presented in Table
4 were lower than $10 \%$, except the total yield under protected cultivation, even so they can be accepted for agronomic experimentation.

The obtained results in relation to the positive effect of the use of clear polyethylene on yield, when compared to black, in the protected cultivation (Table 4 ), are in agreement with those observed by Voth \& Bringhurst (1990) in California, USA, for several strawberry cultivars. On the other hand, the observed results under open field conditions, where no soil mulching effect was verified, are similar to those observed by Martins (1983) in open field cultivation with cv. Campinas, in Viamão, Rio Grande do Sul State, Brazil.

Under protected cultivation conditions, in Spain, Serrano et al. (1992), observed similar results as those presented in Table 4, with regard to the effect of irrigation levels on total yield.

In the open field conditions, the non-influence of irrigation levels on total yield and its components (Table 4) may be associated with the rain events that occurred during the experimentation and the occurrence of diseases in a homogeneous manner in the experiment. Strabbioli (1988), in Italy, also did not observe effects of different irrigation levels on yield, size, and number of strawberry fruits. The author associated this fact to the natural precipitations that occurred during the experimentation.

Fruit yield per plant was high in the protected cultivation (Table 4), ranging from 466.7 to $662.4 \mathrm{~g}$ plant $^{-1}$, when compared to those achieved by Passos (1997) and Fernandes-Jr. et al. (2002), using the same cultivar under protected cultivation.

With regard to open field cultivation, the mean total yield values per plant were always higher than 600

Table 4 - Mean total marketable yield values (g), number of fruits per plant, and mean weight of fruits $\left(\mathrm{g} \mathrm{fruit}^{-1}\right)$ per plant under protected cultivation and open field cultivation, with different soil mulches and irrigation levels (MPa), from June to December 1995 in Atibaia, Brazil. a*

\begin{tabular}{|c|c|c|c|c|c|c|}
\hline & \multicolumn{3}{|c|}{ Protected cultivation } & \multicolumn{3}{|c|}{ Open field cultivation } \\
\hline & Total yield & $\begin{array}{c}\text { Number of fruits } \\
\text { per plant }\end{array}$ & $\begin{array}{c}\text { Mean weight of } \\
\text { fruits }\end{array}$ & Total yield & $\begin{array}{c}\text { Number of fruits } \\
\text { per plant }\end{array}$ & $\begin{array}{c}\text { Mean weight of } \\
\text { fruits }\end{array}$ \\
\hline & g plant ${ }^{-1}$ & & $\mathrm{~g}$ fruit $^{-1}$ & g plant ${ }^{-1}$ & & g fruit ${ }^{-1}$ \\
\hline \multicolumn{7}{|l|}{ Soil mulches } \\
\hline Clear plastic & $654.5 \mathrm{a}$ & $85.7 \mathrm{a}$ & $7.6 \mathrm{a}$ & $656.2 \mathrm{a}$ & $79.3 \mathrm{a}$ & $8.3 \mathrm{a}$ \\
\hline Black plastic & $493.3 \mathrm{~b}$ & $69.5 \mathrm{~b}$ & $7.0 \mathrm{~b}$ & $640.6 \mathrm{a}$ & $75.5 \mathrm{a}$ & $8.5 \mathrm{a}$ \\
\hline \multicolumn{7}{|c|}{ Irrigation levels (MPa) } \\
\hline-0.010 & $662.4 \mathrm{a}$ & $86.4 \mathrm{a}$ & $7.6 \mathrm{a}$ & 629.8 a & $75.1 \mathrm{a}$ & $8.4 \mathrm{a}$ \\
\hline-0.035 & $592.6 \mathrm{a}$ & $80.1 \mathrm{a}$ & $7.4 \mathrm{ab}$ & $659.4 \mathrm{a}$ & $77.8 \mathrm{a}$ & $8.5 \mathrm{a}$ \\
\hline-0.070 & $466.7 \mathrm{~b}$ & $66.4 \mathrm{~b}$ & $7.0 \mathrm{~b}$ & $656.0 \mathrm{a}$ & $79.3 \mathrm{a}$ & $8.3 \mathrm{a}$ \\
\hline $\mathrm{CV}(\%)$ & 18.9 & 7.4 & 5.5 & 9.3 & 4.6 & 4.5 \\
\hline
\end{tabular}

$\mathrm{a}^{*}$ Means followed by the same letter are not different by Tukey test $(P<0.05)$. 
g plant ${ }^{-1}$ for the different water levels and soil mulches (Table 4). These values suggest that the cv. Campinas tolerated well a high level of water in the soil, because in the open field cultivation the plants received more than twice as much water as under protected cultivation (Table 1), and even then maintained a high productivity level. During the entire experimentation period, the soil in question proved to have a good internal drainage. Irrigation management can however save water, energy, and labor, and avoid excess water that favors the occurrence and development of diseases. The obtained productivities under open field conditions in the present study were higher than those obtained by other researches and published in other papers, developed with the same cultivar (Passos, 1982; Martins, 1983; Tessarioli Neto, 1993 and Conti et al., 2002).

\section{CONCLUSIONS}

Protected strawberry cultivation, at irrigation levels of -0.010 and $-0.035 \mathrm{Mpa}$ and the clear polyethylene mulch favored the vegetative growth (plant height, maximum horizontal dimension of the plant, and leaf area index), as well as the total marketable fruit yield and its components (number of fruits per plant and mean weight of fruits).

Open field cultivation, presented no effect of treatments due to rainfall occurrence during the cropping season.

\section{REFERENCES}

ALVES, D.R.B.; KLAR, A.E. Comparação de métodos para estimar evapotranspiração de referência em túnel de plástico. Irriga, v.1, p.26-34, 1996.

ANDRIOLO, J.L.; BONINI, J.V.; BOEMO, M.P. Acumulação de matéria seca e rendimento de frutos de morangueiro cultivado em substrato com diferentes soluções nutritivas. Horticultura Brasileira, v.20, p.24-27, 2002.

CAMARGO, L. de S.; SCARANARI, H.J.; IGUE, T. Ensaio de cultivares e híbridos de morangueiro, Jundiaí. Bragantia, v.33, p.33-42, 1974.

CONTI, J.H.; MINAMI, K.; TAVARES, F.C.A. Produção e qualidade de frutos de diferentes cultivares de morangueiro em ensaios conduzidos em Atibaia e Piracicaba. Horticultura Brasileira, v.20, p.10-17, 2002.

EMPRESA BRASILEIRA DE PESQUISA AGROPECUÁRIA EMBRAPA. Simpósio Nacional do Morango, 3., Encontro sobre Pequenas Frutas e Frutas Nativas do Mercosul, 2. Available in: http://www.cpact.embrapa.br/eventos/2006/ simpósio_morango/index.php. Accessed at: 10 jun. 2006.

FARIAS, J.R.B.; BERGAMASCHI, H.; MARTINS, S.R.; BERLATO, M.A.; OLIVEIRA, A.C.B. Alterações na temperatura e umidade relativa do ar provocadas pelo uso de estufa plástica. Revista Brasileira de Agrometeorologia, v.1, p.52-62, 1993.

FERNANDES-JR., F.; FURLANI, P.R.; RIBEIRO, I.J.A.; CARVALHO, C.R.L. Produção de frutos e estolhos do morangueiro em diferentes sistemas de cultivo em ambiente protegido. Bragantia, v.61, p.25-34, 2002.
GALLETTA, G.J., BRINGHURST, R.S. Strawberry management. In: GALlETTA, G.J., HIMELRICK, D.G. (Ed.). Small fruit crop management. Englewood Cliffs: Prentice Hall, 1990. chap.3, p.83-156.

GOTO, R.; TIVELLI, S.B. Produção de hortaliças em ambiente protegido: condições subtropicais. São Paulo: Fundação Editora da Unesp, 1998. 319p.

HANSON, B.; BENDIXEN, W. Drip irrigation evaluated in Santa Maria Valley strawberries. California Agriculture, v.58, p.48$53,2004$.

HSIAO, T.C.; ACEVEDO, E. Plant responses to water deficits, water use efficiency and drought resistance. Agricultural Meteorology, v.14, p.59-84, 1974.

INSTITUTO DE ECONOMIA AGRÍCOLA. IEA. Área e Produção dos Principais Produtos da Agropecuária - Morango. São Paulo. Available in: http://www.iea.sp.gov.br/out/banco/ menu.php. Accessed at: 10 jun. 2006.

IUCHI, T. Crescimento da planta e do fruto de morangueiro (Fragaria $\mathrm{x}$ ananassa Duch.) em diferentes regimes hídricos. Viçosa: UFV, 1993. 187p. (Tese - Doutorado).

KRÜGER, E.; SCHMIDT, G.; BRÜCKNER, U. Scheduling strawberry irrigation based upon tensiometer measurement and a climatic water balance model. Scientia Horticulturae, v.81, p.409424, 1999.

LIBARDI, P.L. Dinâmica da água no solo. São Paulo: EDUSP, 2005. 335p.

LUCCHESI, A.A.; MINAMI, K. Análise quantitativa de crescimento vegetal em cultivares de morangueiro (Fragaria spp.), sob a influência de fito-reguladores de crescimento. Anais da ESALQ, v.37, p.555-593, 1980 .

MARTINS, N.L.F. Efeitos de coberturas plásticas e orgânicas sobre o rendimento de "frutos" de duas cultivares de morangueiro (Fragaria x ananassa Duch.) e a temperatura do solo. Porto Alegre: UFRGS/Faculdade de Agronomia, 1983. 252p. (Dissertação - Mestrado).

MONTERO, J.I.; CASTILLA, N.; GUTIERREZ DE RAVÉ, E.; BRETONES, F. Climate under plastic in the Almeria area. Acta Horticulturae, n.170, p.227-234, 1985. Greenhouse Construction and Covering Materials, 1984, presented at Karlsruhe.

OLITTA, A.F.L. Efeito da irrigação por gotejo no desenvolvimento vegetativo e produção da cultura do morango (Fragaria sp.). Piracicaba: USP/ESALQ, 1980. 79p. (Tese - Livre-Docência).

PASSOS, F.A. Caracterização de clones nacionais e introduzidos de morangueiro (Fragaria x ananassa Duch.), visando o uso imediato na horticultura e o melhoramento genético. Piracicaba: USP/ESALQ, 1982. 116p. (Dissertação - Mestrado).

PASSOS, F.A. Influência de alguns sistemas de cultivo na cultura do morango (Fragaria x ananassa Duch.). Piracicaba: USP/ESALQ, 1997. 106p. (Tese - Doutorado)

PASSOS, F.A.; TRANI, P.E.; BETTI, J.A.; TANAKA, M.A.S. Morango. In: INSTITUTO AGRONÔMICO DE CAMPINAS. Instruções agrícolas para o Estado de São Paulo. 6.ed. Campinas: IAC, 1998. p.222-225. (Boletim, 200).

PEZZOPANE, J.E.M.; PEDRO JR., M.J.; ORTOLANI, A.A. Modificações microclimáticas provocadas por estufa com cobertura plástica. Bragantia, v.54, p.419-425, 1995.

PIRES, R.C.M.; FOLEGATTI, M.V.; PASSOS, F.A. Estimativa da área foliar de morangueiro. Horticultura Brasileira, v.17, p.86-90, 1999.

RAIJ, B. van; CANTARELLA, H.; QUAGGIO, J.A.; FURLANI, A.M.C. (Ed.). Recomendações de adubação e calagem para o Estado de São Paulo. 2.ed. Campinas: IAC, 1996. 285p. (Boletim Técnico, 100).

SERRANO, L.; CARBONELL, X.; SAVÉ, R.; MARFÀ, O.; PEÑUELAS, J. Effects of irrigation regimes on the yield and water use of strawberry. Irrigation Science, v.13, p.45-48, 1992.

STRABBIOLI, G. A study on strawberry water requirements. Acta Horticulturae, n.228, p.179-186, 1988. $4^{\text {th }}$ International Symposium on Water Supply and Irrigation in the Open and Under Protected Cultivation, 1985, presented at Padova. 
TESSARIOLI NETO, J. Influência de cobertura permeável e impermeável sobre o solo e planta na produção do morangueiro (Fragaria x ananassa Duch.). Piracicaba: USP/ESALQ, 1993. 112p. (Tese - Doutorado).

ULRICH, A.; MOSTAFA, M.A.E.; ALLEN, W.W. Strawberry deficiency symptoms: a visual and plant analysis guide to fertilization. Oakland: University of California, 1980. 58p. (Publication, 4098).

VOTH, V. Grapes and berries. Part II - Strawberries. In: HAGAN, R.M.; HAISE, H.R.; EDMINSTER, T.W. (Ed.). Irrigation of agricultural lands. Madison: ASA, 1967. chap.37, p.734737.
VOTH, V.; BRINGHURST, R.S. Culture and physiological manipulation of California strawberries. HortScience, v.25, p.889-892, 1990 .

Received November 29, 2005

Accepted July 09, 2006 